\title{
OVERVIEW OF ECONOMIC RELATIONS BETWEEN THE ISLAMIC WORLD AND THE WEST
}

\author{
Dr. Khalid Mohammed Azab*
}

\section{Introduction:}

Strong economic ties have linked the Islamic world and the West since Islam conquered the lands of Greater Syria (Bilad al-Sham), Egypt and Africa. These relations have progressed as economic prosperity became for both sides the sign of military and political supremacy. At the same time, the balance of powers was equal at many phases of history, such as the era of joint rule of Greater Syria during the Crusades ${ }^{(1)}$, or the mutually profitable economic exchanges that took place between the Mamlukes in Egypt and Syria and the republics of Venice, Pisa and Genoa.

* Member of Egypt's Supreme Council for Archaeology (Formerly the Egyptian Antiquities Department), member of the General Association of Arab Archaeologists, Member of the Egyptian Society for Historical Studies, Director of Information at the Bibliotheca Alexandrina.

\section{Economic Relations Prior to Islamic Conquests}


Under Byzantine rule, Syria and Asia Minor achieved tremendous economic prosperity despite the devastating impact of earthquakes and Persian raids on some of their parts, which prosperity lasted until early in the $7^{\text {th }}$ century AD. The introduction of silk worm cultures late in the 6th century $\mathrm{AD}$ came to consolidate the economic prosperity generated by the production of raw silk and the trading activity with most countries of the Mediterranean Sea. In those times, world trade was monopolized by Eastern merchants from Syria and Greece. In fact, late in the $6^{\text {th }}$ and early in the $7^{\text {th }}$ centuries AD, Syrian merchants residing in France imported spices, wines and papyrus to Marseilles and distributed them from there to cities such as Paris and Tours. A considerable community of these traders settled in every important trading centre. Greek trading in the provinces also thrived but to a much lesser extent. The East had a large demand for cereals from Sicily, wheat and olive oil from North Africa, wood and salt from the Adriatic Sea, iron ore and other minerals from Spain, as well as fruits and other crops. This demand was no lesser than the West's need for spices, papyrus, wines, silks and other textiles as well as for other luxurious goods manufactured in Alexandria, Syria and Constantinople ${ }^{(2)}$. Byzantium's attempts to deviate the routes of northern trade away from Iran, stop the imports of raw silk by boosting its local production, or force Persian importers to adhere to the prices they set for procuring silk, were all doomed to failure. The Byzantine Empire continued to rely on Persia as a trading intermediary while at the same time paying subsidies to the Sassanids. This, however, did not mean that the Empire's riches all went to the Levant. In fact, successful industries in Syria and Constantinople created a measure of balance in the trade exchanges with Persia. Towards the middle of the $6^{\text {th }}$ century, the Byzantine currency had become an unrivalled international currency in the Indian Ocean, ruled over by the Persians at the time. The Sassanid rulers never cast their own gold currency and remained content dealing in the silver Byzantine one, which is a clear indication of the economic supremacy of the Byzantines. ${ }^{(3)}$

\section{Islamic Conquests and their Repercussions}

Trading conditions remained as they were throughout the first half of the $7^{\text {th }}$ century $\mathrm{AD}$ (first quarter of the $1^{\text {st }}$ century $\mathrm{AH}$ ) in the Mediterranean Basin. At first, the Islamic conquests did not dramatically alter the situation. By taking control of Persia and Iraq, the Islamic State became heir to the Persians' trading activity in the Far East, and by conquering Greater Syria and Egypt, it gained an opening onto the Mediterranean Sea, which was Persia's never fulfilled dream.

The position of advanced fortified positions, including Armenia and the Syrian ones on the Mediterranean Sea, acquired crucial importance as 
trading posts for the onward distribution in the West of goods conveyed by Muslims from the East. Conquered populations soon came to the realization that the Arab conquerors were not Barbarians or tyrants intent on disrupting the flow of economic life, but rather a people who encouraged and protected trade to ensure that it remained on its due course. ${ }^{(4)}$

\section{Arabization of the Dinar}

Caliph Abdulmalek Ibn Marwan nurtured a desire to confer an Arab cachet on the State institution, following a well devised and tight policy which he applied to all administrative and economic fields and which included the arabization of the currency. The minting of Arab coins that carried the engraved name of the caliph, prince or ruler was an expression of the Islamic State's sovereignty and its freedom from any foreign dominion. It was upheld then that no economic freedom could be achieved while currencies within Arab countries remained under the economic domination of Byzantium or Persia. Abdulmalek set about achieving economic independence through the arabization of the currency, carried out as part of a global plan to unify all financial systems in the State. These were sometimes Byzantine and other times Sassanid and generated major discrepancies in terms of Jizya rules, income tax (kharaj), and commercial taxes in Iraq and Persia on the one hand, and Syria and Egypt on the other. The downfall of the Persian Empire at the hands of Arabs and the escalating tensions with the Byzan-tine Empire finally caused a shortage in the currency in circulation, leaving no option but to coin Arab currency to make up for this shortfall. ${ }^{(5)}$

From the Umayyad era, Islamic economy grew exponentially with the constraints imposed by the Byzantine administration on the trading activities of its subjects. The Byzantine State did not have a trade-geared mind and its trading interests were not motivated by a desire to boost trade for profit purposes but mainly by a thirst for control and power. ${ }^{(6)}$ This led to the gradual deterioration of economic conditions in Constantinople and the expansion of Islamic trade. We need only follow the triumphs of the Islamic dinar as a transaction means throughout the world in the Middle Ages. Recent archaeological finds in a number of locations have revealed immense quantities of Islamic coins in Russia, Finland, Scandinavian countries and the Balkans. Diverse lines of Islamic coins were found in areas as remote as Britain and Iceland. Most of these coins date back to an era between the end of the $7^{\text {th }}$ century and the $11^{\text {th }}$ century $\mathrm{AD}$, a clear indication of the economic supremacy of Muslims at that time. ${ }^{(7)}$

The economic prosperity of the Islamic world reached its apogee when international trading led by Muslims generated unprecedented wealth for every tradesman and for the State. In the $10^{\text {th }}$ century $\mathrm{AD}$, historians recorded astrono- 
mical figures in description of the wealth and prosperity in the lands of Islam, east and west. The revenue of trading in the cities of Aleppo and Damascus, in Syria, and in Bayt Al Maqdiss, was estimated in 908 AD at 2000000 gold dinars without suffering the inflation trends that we experience today and keeping in kind the high purchasing power of the times. Further west, wealth reached unimaginable proportions in Al-Andalus. The travel chronicler Ibn Hawqal (976 AD) narrates that under Abdulrahman III, the Umayyad caliphate in Cordoba managed to generate revenue amounting to 20000000 gold dinars from trading in the gold of West Africa that the caravans conveyed to Sijilmassa and Marrakech between 912 and 951 AD. ${ }^{(8)}$

For the Byzantine Empire, economic relations with the Arabs were crucially important, not only in trading terms but as a means of consolidating its inter-national status vis-à-vis Arabs and Europe. In fact, prior to the Crusades, most goods from the Muslim East were brought into Europe via Byzantine, a passage that hugely profited Byzantium as a crossroads between the East and the West. But the Crusaders established direct trading relations between Europe and the East, causing Byzantium's economic prosperity to decline soon after and economic supremacy to shift to Italian cities such as Venice and Genoa. ${ }^{(9)}$

\section{Joint Rule Territories}

The Crusades imposed a somewhat different type of relations between the Islamic World and the West. The Crusade on Syria was followed by great economic and political instability, particularly with regard to the lands in dispute and to boundaries. The emergence of a new order was therefore a must in order to resolve those problems, giving rise to what came to be known as the territories under joint administration. At a closer look, the system, with its components and configuration, was a vanguard solution compared to the solutions applied today to resolve border issues. ${ }^{(10)}$ With the passage of time, the status of these border zones evolved and they became jointly administered by the Franks and Muslims. This joint administration was carried out by two representatives, one for the Sultan and one for the Frank prince or king who concluded the administration agreement. The terms of the agreement stipulated that no single party could take control of one aspect without mutual agreement. ${ }^{(1)}$

Joint administration agreements guaranteed the safety and security of the representatives of the two parties and facilitated coordination between them. To resolve any problem arising from the daily interactions between Muslims and Franks in jointly administered lands, as well as in other territories where the two parties operated, special clauses were introduced to govern transactions and resolve any potential issues that may arise. The 
fundamental rule that prevailed in all these clauses was that the Islamic Law (Sharia) would be applied where the person involved was Muslim while Frankish legislation would apply to Franks. ${ }^{(12)}$

As for taxes and levies, they were equally divided between the Sultan and the Frank representative in all jointly administered lands. These levies covered the resources and economic utilities known and in operation at the time such as orchards, fisheries, salt mines, summer and winter crops, mills, and cattle, or the levies imposed on any goods transiting via the country and its ports. ${ }^{(13)}$

In addition to Christian merchants from the Levant, Muslim tradesmen played a crucial role in transporting the various goods flowing between the two communities. Modern sources indicate the existence between these tradesmen of close ties that transcended all religious affiliation. The Andalussi chronicler Ibn Jubayr wrote in this regard: "The journeys of Muslims from Damascus to Akka and even those of Christian merchants are neither stopped nor hindered." $\mathrm{He}$ goes on to say: "It is one of the miracles of this world that Muslim caravans set sail for Frankish lands and that the latter's goods flow unhindered into Muslim lands." (14) Ibn Al Athir, Burchard and Ludolf further document and confirm the good relations that thrived between Muslim and Frank merchants in the cities under Frank dominion and that many cities such as Akka, Beirut and others were bustling with Muslim merchants. ${ }^{(15)}$

Furthermore, a number of towns under Frankish rule were renowned for old traditions in manufacturing goods that were essential to Muslims. Sources report for example that long before the Crusades, the town of Tiberias (Tabariyya) was renowned for mat and rug weaving, popular among Muslims in the Maghreb and the Mashreq, particularly prayer mats of which the price could reach at times 5 gold dinars. ${ }^{(16)}$

In turn, Frankish nobility often commissioned Syrian goldsmiths in the lands under Muslim rule to craft jewels for them as well gold and silver ecclesiastic vessels and recipients which were richly inlaid with precious stones and ivory and adorned churches ${ }^{(17)}$. Their castles and houses were adorned with such pieces and lit with candles made in Islamic cities such as Damascus and other places famous for candle-making. The Andalusian Ibn Jubayr narrates that the return voyages of the Italian boats that used to transport people on a pilgrimage to the holy land were financed with the proceeds from various Syrian goods. ${ }^{(18)}$

\section{The Mamelukes and the Italian Republic}


The $13^{\text {th }}$ century came to an end with the disintegration of the Crusade principalities while the $14^{\text {th }}$ century was marked by the West's strong reaction to this drastic end. The counter reaction took shape in a ban issued by the Pope against trading with the Mameluke State, with the Pope threatening to disown any Frankish merchant who disobeyed the ordinance. The Papal institution resorted to force to put this policy into effect sending armed ships to waylay any Frank merchants who continued to disregard the Church's orders. Strategically, the Catholic Church believed that the mere fact of stopping Frankish trading with the Mameluke State would deprive it from its main source of wealth and power, thus weakening it and making it an easy to destroy target. And once this was achieved, the West would be able to reclaim Jerusalem with little difficulty. The flow of merchandise between the East and the West in the Middle Ages was indeed the main source of revenue for the Mamelukes generated in the form of taxes and levies and the proceeds of its activity as an intermediary.

\section{Reaction of Italian Cities to the Ban}

The Italian republics and cities with Mediterranean naval sovereignty were highly inconvenienced by this ban and therefore chose to continue trading with the Levant by all means, the pursuit of material gain superseding all spiritual considerations. On the one hand, they benefited from the endeavours of the Mameluke authorities to thwart this economic siege by warmly welcoming Frankish merchants in general and those from Genoa and Florence in particular, granting them preferential treatment and many commercial privileges by virtue of the trading conventions concluded with their governments and republics. On the other hand, they sought to obtain the Pope's permission to resume trade with Egypt, fearful that this may result in the economic downfall of Italian cities, particularly Venice. And Pope Clement VI did indeed allow Genoa to send its vessels to Alexandria and other ports of the Sultanate on condition that only authorised merchandise is carried (non-military). To obtain this permission, Venice paid huge amounts to the Pope's entourage. ${ }^{(19)}$

\section{Fall of Constantinople and its Repurcussions}

The economic prosperity registered during the Mameluke era was mainly owed to the intense activity on the naval and land routes linking the caliphate to the East on the one hand and to the West on the other, particularly in the second half of the 15th century. In Egypt and Syria, the Mamelukes served as middlemen for major Eastern goods such as spices, slaves, precious stones, medicine, Chinese incense, timber and others, to such extent that trade with the Levant became intrinsically linked to the fortune, power and might of the Sultanate. 
Trade with the Mamelukes had historical roots. Changes in the political situation in the Eastern part of the Mediterranean helped the Red Sea regain its position as a main trade channel between India and Southern Europe. The deterioration of security conditions in Persia was the primary albeit not the only cause for this shift. In 1434 AD, Genoa occupied Famagosta and the Venetians were forced to retreat from Cyprus. In $1375 \mathrm{AD}$, the Mamelukes conquered the Kingdom of Minor Armenia and put an end to the prosperous Laiazzo trade there. Similarly, towards the end of the last decade of the 14th century, Timur Lang destroyed Astrakhan and the other thriving trading posts along the land route linking Middle Asia to the Black Sea. ${ }^{(20)}$ The Ottoman expansion into the Aegean Sea and the Balkans and the locking of the Black Sea forced the Genoans, the Venetians and other trading states in Southern Europe to intensify their commercial activity with the Mamelukes. With the fall of Constantinople in 1453, Egypt and Syria became the beating heart of Eastern trade. At that juncture, only Italian merchants could obtain spices and other Eastern goods. ${ }^{(21)}$

As a result, Alexandria and Beirut became major trading posts for such goods. Venice and other European countries hastened to conclude agreements with their governments and secure multiple trading privileges and benefits for their cities. After $1453 \mathrm{AD}$, merchant vessels navigated the waters east of the Mediter-ranean in large numbers. The Republic had three shipping lines with the East, and a fourth one called Di Trafego which was launched in $1461 \mathrm{AD}$ and linked Tunis to Alexandria. Merchants from Genoa, Florence, Napoli and Acona also obtained many privileges and sailed their laden vessels towards Alexandria, Beirut and other major trading posts of the Mameluke Sultanate. ${ }^{(22)}$

Trade exchanges between the Mamelukes and Italian cities made the Italian currency an important element on Mameluke markets. In fact, Italian golden ducats were the basis of any trade agreement or exchanges between Italian cities and Mameluke authorities and were the latter's currency of choice for trading, particularly Venetian ducats ${ }^{(23)}$, a clear indication of the economic supremacy of Italian cities. Investments of Italian cities in the Mameluke sultanate towards the end of the 15th century are thought to have exceeded 800000 gold ducats which clearly shows the powerful economy of these cities. ${ }^{(24)}$ However, the discovery of the Cape of Good Hope signalled the beginning of the end of Mameluke State and economic prosperity in the Islamic world, and the beginning of Western domination over international trade. The threat to the source of revenue of the Mameluke State was one of the direct causes of its fall in the hands of the Ottomans. 
On 20 May 1498 AD, and after several attempts by others who preceded him, Vasco de Gamma discovered a route to India and reached Calcutta by sea on board three Portuguese ships. This discovery represented a momentous turning point of which the implications were only truly gauged later when the Portuguese laid claim to the Indian Ocean coasts, locking this ocean exclusively for their use, and controlling India's trade and the trading routes leading from there to the West. ${ }^{(25)}$ Many clashes occurred between the Mamelukes and the Portuguese during the reign of Qansoua Al Ghuri (906$922 \mathrm{AH}-1501-1516 \mathrm{AD}$ ) as he tried to break the siege imposed on the region and which threatened to suffocate it.

Mahmud Khan I (1458-1511 AD), ruler of Gujarat, India, appealed to Al Ghuri asking for urgent help against the tyranny and assaults of the Portuguese on the region. The Mameluke sultan dispatched his armada only to be defeated at the Dio sea battle on the shores of India in 1509AD. During this famous battle, the Portuguese commander De Almeida destroyed the Mameluke armada and inflicted huge losses upon the army. The Portuguese equally made several attempts to invade Arab coasts on the Red Sea and the Gulf up until the Ottomans put an end to their influence and expansionist plans in the region. ${ }^{(26)}$

The end of Mameluke domination over trade routes impacted negatively on the domestic situation in Egypt as oppression and plagues spread, and the State easily caved in before the Ottomans in 1516-1517 AD. The Ottomans' conquest of Egypt heralded a new era of economic relations between the East and the West. The Islamic world did not surrender to the West's economic domination and instead resisted, helped in this process by the existence of the powerful Ottoman Empire which managed to make this world a vast but unified space and a market for the exchange of goods. Morocco resisted the military dominance of the West and raided European coasts, forcing European countries such as Denmark (1757 AD) and Sweden $(1763 \mathrm{AD})$ to enter into friendly trade agreements with it ${ }^{(27)}$. A most eloquent example of the nature of economic relations between the Islamic world and the West was the Austrian thaler. 


\section{Austrian Thaler}

Many European currencies were put in circulation in the Islamic world during its regression phases which began in the 10th century AH/16th century AD and reached an abysmal level in the 13th and 14th centuries AH/ (9th and 20th centuries AD). Among these currencies were the silver coins known as the rial, an appellation borrowed from the Spanish word real meaning 'royal'. These currencies were diverse and included French, Spanish and Dutch ones. ${ }^{(28)}$

Prominent among these currencies was the Austrian thaler. The silver mines of Middle Age Europe witnessed feverish activity in the 15th century AD after the discovery of new smelting methods that made possible the isolation of silver from copper ${ }^{(29)}$. The Roman Empire ${ }^{(30)}$, which ruled over Germany and Austria, benefited from this activity and issued silver coins. These coins reached the far corners of the Ottoman Empire and Middle Asia where they gradually replaced the Ducth thalers (Al Arsalani). The Austrian money was known as the riyal or Qurrat Qurush (meaning black schillings as opposed to red ones -Qazal)-, as it was made of better quality silver, contrary to the mixed silver coins which contained a high percentage of copper and which were referred to by the Turks as Qazal (meaning red). ${ }^{(31)}$

These silver coins which appeared towards the end of the Middle Ages represented the first documented European coins and were the largest coins minted at the time. Having started in Tyral (currently Austria), the casting of the thaler coin spread to several parts of Germany and Bohemia (Czechoslovakia prior to its partition into two countries). The counts of Bohemia cast their coins in silver mined from Jodchims Thal, which gave birth to the currency name Jodchims thaler, later on abbreviated to thaler which came to refer to any silver currency. The thaler is considered the ancestor of the current word 'dollar'. ${ }^{(32)}$

Far away from Bohemia, the thaler was known in Germany as Reishs thaler and also referred to as Risdale or the contractual rial used as the currency of transactions. It was minted by several countries to be used in trade exchanges with various nations, which applied most particularly to the Austrian Risdale. Several issues of the Austrian imperial thaler were minted following the characteristics of the provinces where they were minted. The most popular thalers in Eastern markets depicted Marie Therese, the Empress of Austria who died in $1780 \mathrm{AD}$ (which date was engraved on one side of the Real).

\section{The Thaler in Egypt}


The imperial thaler appeared in Egypt much later than it did in Turkey where it was in use since the $15^{\text {th }}$ century. Its first mention came in the accounting books of noblemen where mention was made of Qirsh Abu Taqa in $1043 \mathrm{AD}$. Its mention in historical documents dates back to Ramadan of $1114 \mathrm{AH}$ when a call was made to set an exchange rate for the Abu Taqa rial $^{(33)}$. The coin was dubbed Abu Taqa in reference to the image engraved on one of its sides, arms dangling from a bow divided into four parts, a symbol that somewhat resembled the squares of a window with iron bars commonly used in Egypt, hence the words Abu Taqa (the one with the window $)^{(34)}$. Starting $1165 \mathrm{AH} / 1751 \mathrm{AD}$, the thaler took over monetary markets in Egypt at the expense of the Spanish rial because of its superior make, its perfect round shape and its resistance to erosion. ${ }^{(35)}$ This shift occurred in favor of the thaler despite the fact that the base value of the Spanish rial con-tinued to be slightly higher than the thaler because of the higher number of carats in the Spanish rials. This was attributed to the nature of commercial ties on the one hand, and to the higher weight of the thaler and its superior craftsmanship on the other. ${ }^{(36)}$

\section{Coffee and the Thaler}

The source of the thaler's absolute supremacy in Egypt from the mideighth century and until the French Campaign was mostly Yemen. During this period, the thaler became the most favored currency throughout the Red Sea and the Indian Ocean in view of its close association with the coffee trade. It came into circulation early in that century in Makha (a Yemenite port) and prevailed as from $1760 \mathrm{AD}(1174 \mathrm{AH})$. When Naipur visited Yemen, he noticed that the German currency was widely used in Yemen and spread from there to India where it financed the spice and coffee trades. Immense quantities of thalers were shipped from the various European ports towards Alexandria. In $1787 \mathrm{AD}$, the volumes shipped from Marseilles, Livorn and venice reached 480 thousand pieces. ${ }^{(37)}$

Shortly before the French Campaign against Egypt (1798), the imperial thaler (Abu Taqa) became an accounting currency used to gauge agricultural taxes. This unique situation revealed that the thaler had become the major payment currency in Egypt at the time. In a report to his country in $1760 \mathrm{AD}$, the French Consul stated that Egyptians, including the farmers who initially rejected the thaler, now preferred it over gold coins. The imperial thaler had no name in Egypt othen than Abu Taqa and no documents refer to it as the Qirsh as it was commonly known in Turkey (derived from the Austrian name of Grioschen used to refer to silver coins), nor was it known in Egypt as the rial (Abu Shousha) as it was known it other markets in the East. 
Many samples of the Austrian thaler can be found at the Islamic Art Museum in Cairo and all share an engraving of Marie Therese. Albeit some variations in the general design, they all depict an eagle spreading its wings. On its body is the drawing of a shield divided into rectangular shapes similar to windows, hence the name Abu Taqa. The oldest sample at the museum dates back to $1757 \mathrm{AD}^{(38)}$. The Austrian thaler was coined in weights that ranged between 27.67 and 27.92 grams and a diameter of $40 \mathrm{~mm}$.

In the 19th century, the thaler became widely used in vast parts of the world, from the northwest coasts of Africa and Nigeria, Madagascar and Oman, to the Turkish coasts on the Black Sea, all of which were Muslim lands. Another indi-cation of the importance and popularity of this rial was the fact that it was minted as a royal coin in Britain between 1945 and 1958 AD.

Yielding to pressures from Hitler and Mussolini in 1935 AD, the Austrian authorities were forced to hand over the equipment used in casting the Austrian rial to the Italian government which needed to finance Mussolini's war on Ethiopia. Since then, Italy has monopolized the minting of this rial. But the British, who had commercial interests with all their colonies, including Islamic ones, continued to produce this rial at the Royal Mint.

During World War II, the British Government, wishing to cut transport costs, decided to transfer the minting equipment to Mumbai in India where production started. A perfect example of the huge increase in the price of silver is that from 1971 to $1974 \mathrm{AD}$, the price of the Austrian rial in Amman increased from half an Omani Rial to 1.4 of the real. It is interesting that the real is still used in fashioning necklaces worn usually by girls. These necklaces are sometimes supplemented with a talisman or a lucky charm known as $\mathrm{Al}$ $\operatorname{Madhud}^{(39)}$. The rial remained in use in Oman until very recently.

\section{Footnotes:}

(1) See next chapter on "Joint Rule Territories".

(2) Othmane, Fathi: Islamic Frontiers of Byzantine, Book III on Civilizational Interaction (Dar Al Kitab Al Arabi, Cairo, Egypt), page 234 (Original).

(3) Lewis, Archibald : European Naval and Maritime History, translated by Ahmed Issa, pp. 65, 71 and 103.

(4) Othmane, Fathi: op. cit., page 238 (Original).

(5) Nabrawi, Raafat: Story of the First Arab Coins in Islam, pp. 60-61.

(6) Faraj, Wissam: State and Trade in the Middle Byzantine Era, 11, Annals of the Faculty of Humanities, University of Kuwait, $9^{\text {th }}$ Annal, $53^{\text {rd }}$ letter, 1987-1988.

(7) Suryal Atiya, Aziza: Relations between East and West, translated by Philip Seif, authenticated by Ahmed Fati (Dar Thaqafa, p. 157, 1972). 
(8) Ibid, page 156 (Original).

(9) Vasiliev, Alexander: Byzantium and Islam, translated by Hussein Mu'nis and Abdelhamid Zayed, chapter on Byzantium in the addendum to Pines's book 'The Byzantine Empire', pp. 271-282, Fathi Othmane, ibid, page 254.

(10) Al Ghamrawi, Ali: A New Look at Economic Relations between Muslims and Franks in Greater Syria during the Crusades, Addara Magazine, issue 1, 18th year, $1412 \mathrm{AH}$, page 171.

(11) Addawdar, Bebars: Zubdat Al Fikra fe Tarikh Al Hijra, authenticated by Zubaida Mohamed Atta, Riyah, 1394 AH, Vol 9, pp. 195-192. Al Qalqashandi: Subh Al Al A'sha fi Sina'at Al Insha, vol. 14, page 46.

(12) Al Ghamrawi, Ali: op. cit., page 174.

(13) Al Qalqashandi: Ibid, Vol 14, pp. 37-38, Bebars Addawdar: ibid, p. 194.

(14) Ibn Jubayr: The Journey, pp. 235-245, Dar Sader, Beirut, 1964 AD.

(15) Ibn Al Athir: Al Kamil fe Tarikh, Vol. 8, Dar al Fikr, Beirut 1978, page 399. Burhard of Mount Sion: A Description of the Holy Land, in P.P. T.S. Vol. XII, London, 1896, p. 163. Ludof Van Suchen: A Description of the Holy Land, in P.P. T.S. Vol. XII, London, 1896, p. 55.

(16) Khisru, Nasser: Safarnamah, page 53.

(17) Ibid, page 189.

(18) Ibn Jubayr: The Journey, page 287.

(19) Al Khadem, Samir: The Islamic East and the Christian West, Dar Arrayhani, Beirut, 1989, page 12.

(20) Al Khadem, Samir: Ibid, page 329.

(21) Al Khadem, Samir: Ibid, page 329.

(22) Al Khadem, Samir: Ibid, page 196, Raafat An-Nabrawi: Golden Venetian Ducats, Addara Magazine, Issue 4, year 17, Ramadan 1412 AH, page 91, page 122.

(23) Al Khadem, Samir: Ibid, page 415.

(24) Zaki, Naim: Ibid, page 449, Ahmed Fouad Metwalli: Ottoman and Portuguese Navy in the $10^{\text {th }}$ Century AH, Faculty of Social Sciences Magazine, Islamic University of Mohamed Ben Saoud, fourth issue, 1400AH/1980AD, pp. 379-380.

(25) Ahmed Fouad Metwalli: Ibid, pp. 384-385.

(26) Ahmed Ben Al Mahdi Ben Al Ghazal: Outcome of Ijtihad for Peace and Jihad, authenticated by Ismail Al Moghrabi, pp. 7-8, University Publications Compendium, Algeria, 1982 AD. Ahmed As-Sawi: Currencies in Ciculation in Ottoman Egypt, PhD thesis, Faculty of Archeology, Cairo University, page 189.

(27) Fahmi, Abderrahmane: Currency in Circulation in the Days of Jabarti, page 578. Proceedings and papers of a symposium on Al Jabarti, Egyptian Association of Historical Studies, Cairo.

(28) Cf. Gib and Bowen: Islamic Society and the West, Vol. 2, page 105.

(29) Dotey, R.: Money of the World, p. 138. 